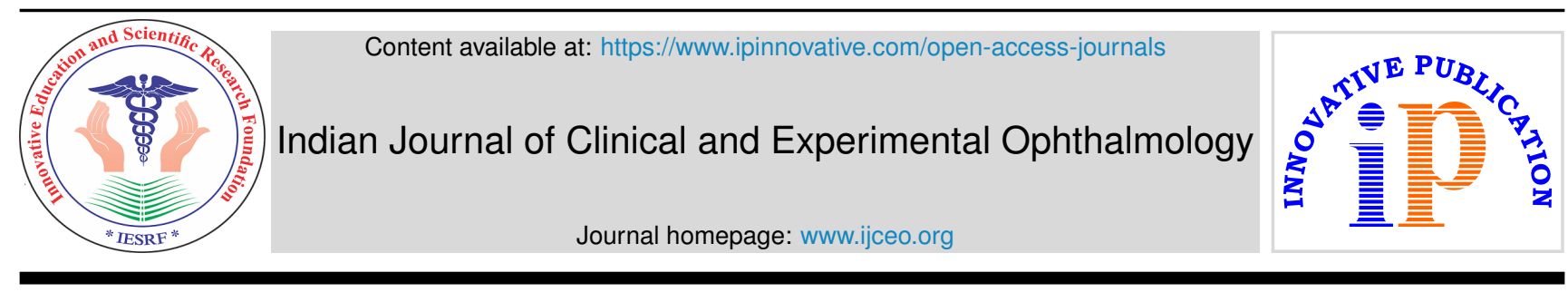

\title{
Editorial
}

\section{Sleep and dry eye disease}

\author{
Rajendra P Maurya ${ }^{1}$, , Shivangi Singh ${ }^{2}$ \\ ${ }^{1}$ Regional Institute of Ophthalmology, Institute of Medical Sciences, Banaras Hindu University, Varanasi, Uttar Pradesh, India \\ ${ }^{2}$ Himalayan Institute of Medical Sciences, Swami Rama Himalayan University, Dehradun, Uttrakhand, India
}

\section{A R T I C L E I N F O}

\section{Article history:}

Received 08-09-2021

Accepted 12-09-2021

Available online 30-09-2021

\begin{abstract}
This is an Open Access (OA) journal, and articles are distributed under the terms of the Creative Commons Attribution-NonCommercial-ShareAlike 4.0 License, which allows others to remix, tweak, and build upon the work non-commercially, as long as appropriate credit is given and the new creations are licensed under the identical terms.

For reprints contact: reprint@ipinnovative.com
\end{abstract}

Dry eye has become the most common ocular surface disease around the world. It is defined by the international TFOS Dry Eye Workshop II (TFOS DEWS II) as a "multifactorial disease of the tears and ocular surface that results in symptoms of discomfort, visual disturbance, and tear film instability with potential damage to the ocular surface." ${ }^{1,2}$ Sleep is essential for optimal health. The American Academy of Sleep Medicine (AASM) and Sleep Research Society (SRS) developed a consensus recommendation that adults should sleep 7 or more hours per night on a regular basis to promote optimal health. ${ }^{3}$

DED can lower work productivity and interfere with daily activities like reading and driving. ${ }^{4}$ The burden of DED not only affects a patient during the day but may also play a role in their experience asleep. Poor sleep quality has been associated with DED, where sleep disturbances appear to have an impact on dry eye symptoms. ${ }^{5}$ The results of closed-eye studies and elevated tear matrix metalloprotease9 in DED suggest that patients with DED may have more inflammatory processes than controls during sleep. ${ }^{6,7}$ Patients with DED have a high prevalence of obstructive sleep apnea, ${ }^{8}$ and its therapy, continuous positive airway pressure, may worsen DED further. ${ }^{9}$

In a study conducted by Ayaki et al. it was seen that there was significantly higher prevalence of sleep disorders in dry eye patients compared to other types of patients in eye

\footnotetext{
* Corresponding author.

E-mail address: mauryarp_bhu@yahoo.com (R. P. Maurya).
}

clinics. ${ }^{10}$ It is estimated that more than $40 \%$ of people with dry eye suffer from poor sleep quality. ${ }^{10,11}$ Recent study conducted by Gangwisch JE suggest that a sleep disturbance is associated with circadian rhythm disruption. ${ }^{12}$ It has also been reported that tear secretion and tear stability have a circadian rhythm, ${ }^{10,13}$

It has been seen that sleep deprived dry eye shows unique pathologic features. ${ }^{14}$ There was a mild increase, although no significant difference, of goblet cell density and MUC5AC expression in the conjunctival tissue after 10 days of sleep deprivation. It could be an adaptive response to the decreased aqueous tear secretion occurring during the early stage of dry eye. Another possibility is that sleep deprivation induced stress which could have promoted the differentiation of goblet cells. ${ }^{14}$ Therefore further study is necessary to observe the goblet cell differentiation even for longer duration of sleep deprivation to investigate the effect of chronic sleep deprivation on goblet cells. A study conducted by Li $\mathrm{S}$ et al. characterized histological lacrimal gland changes induced by sleep deprivation. After 2 days of sleep deprivation, the lacrimal gland underwent hypertrophy, which became more evident at later times without any acinar cell apoptosis. Instead, the acinar cells became enlarged due to lipid droplet accumulation. ${ }^{14}$ Also sleep deprivation reduces tear secretion and impairs the tear film. It has been seen that sleep deprivation shortens TBUT indicating decrease in tear secretion and also increases the VAS pain score. ${ }^{15}$ 
A study conducted by Ayaki et al showed that treatment of DED was more effective in improving sleep and mood problems in patients with newly diagnosed DED than in those with established DED. ${ }^{16}$ In the same study the new initiative of a sleep service was successfully established for patients with DED and sleep problems and on follow up survey after evaluating the patients a satisfactory outcome was obtained from the patients. A few tips about lighting, bedtime, drinking, and shield eyeglasses seemed helpful in supporting their sleep quality. Another large population based survey in Korea revealed that increase in dry eye symptoms were consistent with declining sleep duration. ${ }^{17}$ It was also seen that after treatment of dry eye with hyaluronate, steroid and mucin secretagogue their quality of sleep improved, which further strengthens their association. Conventionally, ophthalmology and psychiatry do not have a close assemblage; however, the results of sleep service suggests the new possibility that liaison psychiatry could be beneficial for some patients with ocular disease, especially DED. ${ }^{16}$ Another DED therapy reported to be effective for sleep and the autonomous nervous system is lid-heating during sleep. ${ }^{18}$

In summary, dry eye disease is common ocular surface disorder which may be complicated by sleep disorders. We as ophthalmologists, should be aware of sleep distress associated with dry eye disease and thoroughly listen to patient's complaints and try to relieve their from distress. We can use eye drops, other ophthalmic interventions, sleep hygiene, and psychiatric consultation to further alleviate their symptoms.

\section{Conflict of Interest}

None.

\section{References}

1. Craig JP, Nichols KK, Akpek EK, Caffery B, Dua HS, Joo CK, et al. TFOS DEWS II Definition and Classification Report. Ocul Surf. 2017;15(3):276-83.

2. Maurya RP, Singh VP, Chaudhary S, Roy M, Srvastav T, Rajan M. Prevalence of severe dry eye disease in postmenopausal women in North India: A teaching hospital study. Indian J Obst Gynecol Res. 2019;6(1):94-6.

3. Watson NF, Badr MS, Belenky G, Bliwise DL, Buxton OM, Buysse $\mathrm{D}$, et al. Recommended Amount of Sleep for a Healthy Adult A Joint Consensus Statement of the American Academy of Sleep Medicine and Sleep Research Society. Sleep. 2015;38(6):843-4. doi:10.5665/sleep.4716.

4. Le Q, Ge L, Li M, Wu L, Xu J, Gong L, et al. Comparison on the vision-related quality of life between outpatients and general population with dry eye syndrome. Acta Ophthalmol. 2014;92(2):124-

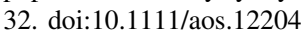

5. Au NH, Mather R, To A, Malvankar-Mehta MS. Sleep outcomes associated with dry eye disease: a systematic review and meta- analysis. Can J Ophthalmol. 2019;54(2):180-9.

6. Ayaki M, Tsubota K, Kawashima M, Kishimoto T, Mimura M, Negishi K. Sleep Disorders are a Prevalent and Serious Comorbidity in Dry Eye. Invest Ophthalmol Vis Sci. 2018;59(14):143-50.

7. Dorennavar L, Maurya RP, Singh VP, Singh MK, Sharma K, Sharma $R$. The role of rebamipide ophthalmic suspension in management of dry eye disease. Indian J Clin Exp Ophthalmol. 2015;1(4):191-6.

8. Karaca EE, Akçam HT, Uzun F, Özdek Ş, Çiftçi TU. . Evaluation of ocular surface health in patients with obstructive sleep apnea syndrome. Ophthalmol. 2016;46:103-8.

9. Hayirci E, Yagci A, Palamar M, Basoglu OK, Veral A. The effect of continuous positive airway pressure treatment for obstructive sleep apnea syndrome on the ocular surface. Cornea. 2012;31:604-8.

10. Ayaki M, Kawashima M, Negishi K, Tsubota K. High prevalence of sleep and mood disorders in dry eye patients: survey of 1,000 eye clinic visitors. Neuropsychiatr Dis Treat. 2015;11:889-94.

11. Kawashima M, Uchino M, Yokoi N, Uchino Y, Dogru M, Komuro A, et al. The association of sleep quality with dry eye disease: the Osaka study. Clin Ophthalmol. 2016;10:1015-21.

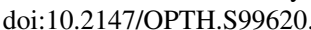

12. Gangwisch JE. Epidemiological evidence for the links between sleep, circadian rhythms and metabolism. Obes Rev. 2009;10(2):37-45.

13. Walker PM, Lane KJ, Ousler GW, Abelson MB. Diurnal variation of visual function and the signs and symptoms of dry eye. Cornea. 2010;29:607-12.

14. Li S, Ning K, Zhou J, Guo Y, Zhang H, Zhu Y, et al. Sleep deprivation disrupts the lacrimal system and induces dry eye disease. Exp Mol Med. 2018;50(3):e451. dol:0/038/emm.201/285

15. Lee YB, Koh JW, Hyon JY, Wee WR, Kim JJ, Shin YJ. Sleep deprivation reduces tear secretion and impairs the tear film. Invest Ophthalmol Vis Sci. 2014;55(6):3525-31.

16. Ayaki M, Toda I, Tachi N, Negishi K, Tsubota K. Preliminary report of improved sleep quality in patients with dry eye disease after initiation of topical therapy. Neuropsychiatr Dis Treat. 2016;12:329-37.

17. Lee W, Lim SS, Won JU, Roh J, Lee JH, Seok H. The association between sleep duration and dry eye syndrome among Korean adults. Sleep Med. 2015;16:1327-31.

18. Yamashiro Y, Igaki M, Sakamoto I, Suzuki A, Niki Y. Effect on sleep of the application of heat and steam generating sheets to the eyes. Jpn J Physiol Anthropol. 2011;16:85-91.

\section{Author biography}

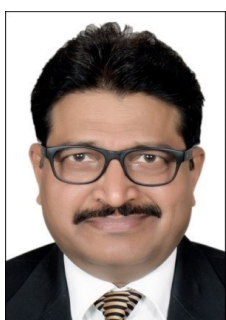

Rajendra P Maurya, Editor in Chief IJCEO, Associate Professor \& I/c Orbit, Ocular Oncology and Oculoplasty Unit Regional Institute of Ophthalmology, Institute of Medical Sciences, Banaras Hindu University, Varanasi, (UP), India E-mail: editorijceo@gmail.com, mauryarp_bhu@yahoo.com

Shivangi Singh, Junior Resident

Cite this article: Maurya RP, Singh S. Sleep and dry eye disease

Indian J Clin Exp Ophthalmol 2021;7(3):452-453. 